\title{
Assessment of mercury pollution sources in beach sand and coastal soil by speciation analysis
}

\author{
José Luis R. Gallego ${ }^{1}$, Maria Antonia López-Antón²*0, Deva Martínez de la Rosa², Eduardo Rodríguez-Valdés ${ }^{2}$,
} Nerea García-González , Elena Rodríguez² and Maria Rosa Martínez-Tarazona²

\begin{abstract}
Background: An essential requisite for controlling and monitoring mercury in the environment is to identify its species in different types of soils and sediments, as this will help not only to establish its mobility in the environment and ecosystem and the degree of its toxicity, but also to establish the source of contamination. The objective of this work was to identify the origin of mercury in beach sands and soil taken from a coastal region with previously high mining and industrial activity by characterizing the mercury species using the technique known as thermal desorption (HgTPD).
\end{abstract}

Results: Apart from quartz, the main mineral species identified in the raw sands and soil were calcite, fluorite and barite. The concentration of mercury ranges from 5 to $23 \mathrm{\mu g} \mathrm{g}^{-1}$, and although it is distributed in different proportions in the function of the size, thermal desorption profiles demonstrated that the mercury species present in the samples do not vary with the mercury concentration and the particle size. By means of HgTPD, mercury oxide (HgO) was identified in the beach sands, whereas mercury sulfide ( $\mathrm{HgS}$ ) was found in the soil sample taken from the vicinity of the beach. Complementary methodologies foster the HgTPD conclusions and verify that mercury is present mostly in insoluble stable (HgS) or low-mobility (HgO) forms in the samples studied. Analyses by ICP-MS after sequential extraction and HPLC separation of mercury species show that inorganic mercury is the predominant form in the samples.

Conclusions: The technique HgTPD is a very useful tool to ascertain the origin of mercury in contaminated beach sands and shoreline soils. In the particular area studied in this work, the species identified indicate that previous mining activity was the source of the mercury and rule out the possibility that contamination is derived from coal combustion activities ongoing in the region.

Keywords: Mercury, Speciation, Thermal desorption

\section{Background}

Mercury is a heavy metal of great concern due to its high level of toxicity and the serious effects it has on health and the environment. Although all mercury species are toxic, certain species-specific toxic mechanisms have been demonstrated to have an effect on human organisms [26]. For instance, methylmercury, which is the species of mercury that can be incorporated into humans

\footnotetext{
*Correspondence: marian@incar.csic.es

${ }^{2}$ Instituto Nacional del Carbón (CSIC), Francisco Pintado Fe, 26, 33011 Oviedo, Spain

Full list of author information is available at the end of the article
}

through food, may cause very serious harm to the central and peripheral nervous system [49]. The enormous alarm caused by mercury toxicity as a consequence of the presence of its compounds in the environment led to the Minamata Convention on Mercury, which came into force in August 2017 [48]. The Minamata Convention is the first global environmental agreement negotiated in the 21st millennium. The objective of the Convention is to protect human health and the environment from anthropogenic emissions and the release of mercury and mercury compounds, and it has set out a range of measures to meet this objective. 
Due to emissions of mercury to the atmosphere and their subsequent deposition onto the land and into the water as a result of the proximity of industrial activity zones or the transport process, some areas may contain high concentrations of mercury [32, 35]. In addition, point-source pollution associated with the inappropriate disposal of mining waste, metal smelters and other industrial activities have increased the environmental threat from mercury [9, 18, 31, 46]. Asturias, NW Spain, has had a long history of industrial activity, especially in the form of coal mining, but mercury mining and metallurgy were also important activities up until the end of the 1970s. This, coupled with other industrial processes, such as coal combustion, the production of steel and cement, exposed the region's soils, beaches and coastal environments to the risk of contamination (see e.g., $[6,42]$ ), especially by mercury [21, 27, 34]. Local and regional studies based on geological records, such as peat bogs or estuarine sediments, have also revealed a dramatic increase in mercury accumulation over the last 200 years $[15,23$, $25]$. On a global scale, coal combustion and the production and processing of metals are the main anthropogenic sources of mercury emissions in Europe and the USA [11, 47]. The contamination of beaches by mercury comes mainly from anthropogenic sources such as industrial waste, stormwater runoff and sewage outfalls $[10,13,29]$. Chlor-alkali plants are also important sources of mercury, and the area surrounding these plants has been found to have high mercury concentrations [4]. Proximity to such industrial activities is in itself suggestive of the source of mercury contamination, but when several different activities occur in the same area or when the polluting species are transported by air or water from elsewhere, the origin of the mercury species is often difficult to pinpoint. Ascertainment of the source of mercury contamination will help to determine the risk of exposure, and being able to determine the chemical form (speciation) of the mercury present in the land is essential for understanding and modeling metal-contaminated systems since the way in which the mercury compounds are distributed determines their environmental mobility and bioavailability [14].

The objective of this study is to identify the mercury species present in samples of beach sands and soil taken from a coastal area of Asturias by the technique based on programmed temperature desorption (HgTPD) [3, 5, 36, 37]. Because the samples come from a region (Asturias), where different industrial activities have taken place, the study aims to relate the species of mercury to their source of origin.

\section{Experimental part}

\section{Site description and samples}

During a sampling campaign of 13 sandy beaches with dunes in the Cantabrian area (unpublished data), it was found that sand samples from the Vega beach (Asturias, NW Spain) showed anomalously high mercury concentrations when compared to other areas sampled. The high mining and industrial activity in this region (Fig. 1a) suggests several possible sources for the presence of this heavy metal. Accordingly, three different composite samples were taken for a comprehensive addressing of mercury sourcing (Fig. 1b), namely A1 (supratidal sand), A2 (white dune) and S1 (coastal soil on the shoreline). Each sample was composed of five increases taken from each vertex of a $1 \mathrm{~m}$ edge square and its central point, from the top $30 \mathrm{~cm}$ of the material, using an Edelman Auger (Fig. 1b). In situ sieving of the samples through a $2-\mathrm{cm}$ mesh screen was carried out to remove the large material and then the remaining samples were kept in plastic bags until their pre-treatment in the laboratory. Afterward, the samples were dried in an oven at $30{ }^{\circ} \mathrm{C}$ to prevent the volatilization of the mercury. The fractions smaller than $2 \mathrm{~mm}$ were separated by dry sieving, and the representative subsamples were generated using a riffler.

\section{Devices for mercury determination and speciation}

The concentration of total mercury in the raw samples and in the sieved sub-size fractions (see below) was determined by means of a mercury analyzer (AMA 254). The mercury species were identified by temperature-programmed desorption (HgTPD) using a setup developed by the authors [38]. This device consists of a temperatureprogrammed furnace coupled to a PYRO 915 furnace from LUMEX and a continuous mercury analyzer (RA915) [39]. The peculiarity of this device is that the mercury species are desorbed in the first furnace using $\mathrm{N}_{2}$ as an inert gas, while at the same time $\mathrm{O}_{2}$ is introduced into the PYRO furnace to ensure the total decomposition of volatile matter. Desorption profiles are obtained by heating the sample at a rate of $50{ }^{\circ} \mathrm{C} \mathrm{min}{ }^{-1}$ under a $\mathrm{N}_{2}$ flow of $500 \mathrm{~mL} \mathrm{~min}^{-1}$. The PYRO 915 unit is kept at approximately $800{ }^{\circ} \mathrm{C}$ under an $\mathrm{O}_{2}$ flow of $500 \mathrm{~mL} \mathrm{~min}^{-1}$. In this unit, all the mercury species that have been vaporized from the sample in an inert atmosphere are transformed into elemental gaseous mercury $\left(\mathrm{Hg}^{0}\right)$. $\mathrm{As}^{\mathrm{Hg}}$ reaches the detector in the continuous analyzer, the software registers temperature or time versus mercury and records the desorption profiles that correspond to the evaporation of the mercury species present in the sample. Each desorption peak is assigned to a species of mercury in accordance with the reference database of pure mercury compounds prepared in concentration and with matrices 


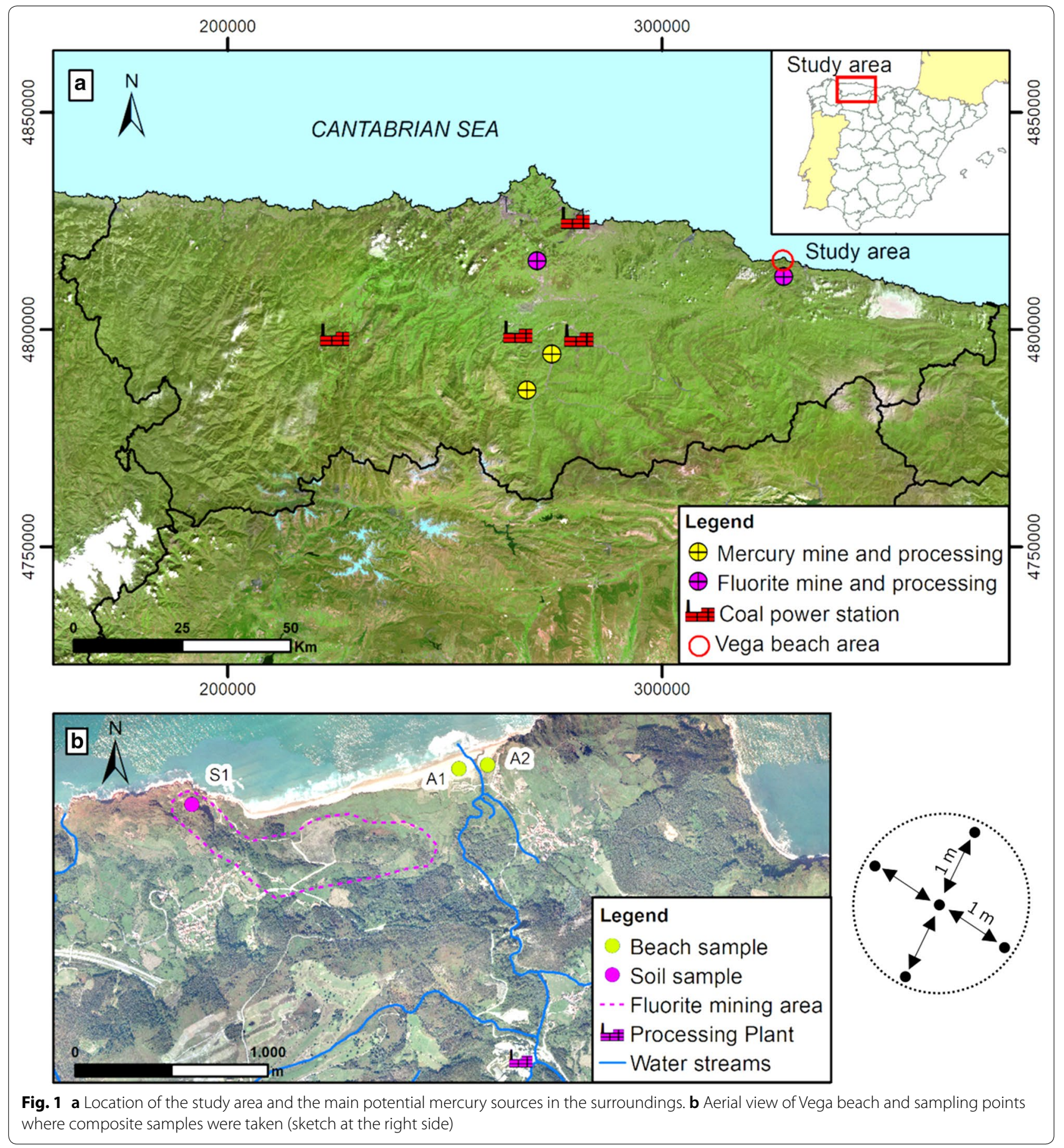

similar to the selected samples. Mercury reference materials used in this study included $\mathrm{HgS}, \mathrm{HgO}, \mathrm{Hg}^{0}, \mathrm{HgCl}_{2}$ and mercury associated with humic acid ( $\mathrm{Hg}-\mathrm{HA})$.

In addition to the total mercury content analyzed in the AMA equipment, the determination of the identified species was carried out in the HgTPD device. The equipment was calibrated for total mercury content by analyzing reference samples containing different amounts of $\mathrm{HgS}$ in a pure commercial sand matrix. The detection limit of the system was $3 \mathrm{ng}$ for a maximum sample weight of $100 \mathrm{mg}\left(0.03 \mathrm{mg} \mathrm{kg}^{-1}\right)$, assuming that the release of all the $\mathrm{Hg}$ occurs in a single peak. Each mercury standard and sample were analyzed 2 to 4 times. The precision of the analysis was evaluated from the standard deviation 
(SD) and relative standard deviations (\%RSD). An RSD value $<10 \%$ was achieved.

To balance the HgTPD study, two supplementary techniques were applied. First, a sequential extraction [45] was conducted. In brief, extracts with solutions of increasing strengths were attained from subsamples of the samples under study; i.e., the following fractions were obtained: exchangeable (extracted in $\mathrm{MgCl}_{2}$ ), carbonate-bound (extracted in a buffer of $\mathrm{CH}_{3} \mathrm{COONa}$ / $\mathrm{CH}_{3} \mathrm{COOH}$ ), $\mathrm{Fe}-\mathrm{Mn}$ oxide-bound (extracted in $\mathrm{NH}_{2} \mathrm{OH}-\mathrm{HCl}$ ); organic matter-bound (extracted in several steps using $\mathrm{H}_{2} \mathrm{O}_{2}, \mathrm{HNO}_{3}$ and $\mathrm{NH}_{4} \mathrm{NO}_{3}$ ); and the residual fraction (extracted in aqua regia); in all fractions, the supernatants were separated after centrifugation for $15 \mathrm{~min}$ at $8000 \mathrm{rpm}$, filtered and analyzed in an Agilent Technologies 7700 ICP-MS (inductively coupled plasma mass spectrometry). In addition, a second approach by chemical speciation was also performed after extraction of representative subsamples using a solution of $7.6 \%$ $\mathrm{HCl}$ and 10\% 2-mercaptoethanol in an ultrasonic bath. The extract was then centrifuged and diluted. The determination was carried out in a 1260 Infinity HPLC coupled to a 7700 ICPMS, using a ZORBAX Eclipse XDB C18 $(2.1 \mathrm{~mm}$ i.d. $\times 50 \mathrm{~mm}, 5 \mu \mathrm{m})$ column and $0.06 \mathrm{M}$ ammonium acetate, $5 \%$ methanol and $0.1 \% 2$-mercaptoethanol $(\mathrm{pH}=6.8)$ as mobile phase.

\section{Complementary analyses}

Granulometric separation was performed in three fractions $(800-224 \mu \mathrm{m}, 224-125 \mu \mathrm{m},<125 \mu \mathrm{m})$, to ascertain the distribution and speciation of mercury as a function of its size and composition. Fraction $>800 \mu \mathrm{m}$ was rejected as no mercury was detected in this fraction. Before being examined, the material was cleaned to eliminate any possible remains of vegetal matter or fauna from the samples.
The mineral species of the samples were identified by $\mathrm{X}$-ray diffraction (XRD), in a Bruker D8 Discover apparatus with $\mathrm{Cu} K \alpha$ radiation $(\lambda=1.54059 \AA)$. The scan was performed between $10^{\circ}$ and $90^{\circ}(2 \theta)$ using a step size of $0.02^{\circ} \mathrm{s}^{-1}$ and a step time of $2 \mathrm{~s}$.

\section{Results}

The concentration of mercury in the raw sands and soil, and in the different size fractions together with the minerals identified by XRD, is shown in Table 1; note that mercury values found in the raw samples are well above the background/screening levels valid in the region [7]. As might be expected, the main mineral species identified was quartz in all the samples (Additional file 1: Figure S1). Calcite was also present in the sands and in the soil in different proportions. However, there was also an abundance of other minerals such as fluorite in all of the samples and of barite in two of them.

As can be appreciated from the data, the mercury content of the raw samples selected for this study ranges from 5 to $23 \mu \mathrm{g} \mathrm{g}^{-1}$. Moreover, the mercury concentration is distributed in different proportions in the separated fractions (Table 1), the highest concentration being found in the fraction of the smallest particle size. As mentioned above, the objective of this work was restricted to identifying the mercury species and relating them to their origin in a particular area. Extensive samplings and analyses of the area are being carried out with the aim of creating a catalog of the type and level of contamination of this coastal area. Although the analyses performed for this study do not provide yet a conclusive picture about the pollution of the total area, as a preliminary study it may serve to identify the mercury species and to relate them to the source of contamination.

Figure 2 shows the thermal desorption profiles of the beach sands and soil together with the mercury standards used as reference materials. As shown in Fig. 2a-c,

Table 1 Mercury concentrations and mineral compositions of the raw samples and fractions

\begin{tabular}{|c|c|c|c|c|c|}
\hline \multirow[t]{2}{*}{ Sample } & \multirow[t]{2}{*}{ Fraction $(\mu \mathrm{m})$} & \multirow[t]{2}{*}{$\%$ wt } & \multicolumn{2}{|c|}{$\mathrm{Hg}\left(\mu \mathrm{g} \mathrm{g}{ }^{-1}\right)$} & \multirow[t]{2}{*}{ Mineral } \\
\hline & & & Fraction & Raw sample & \\
\hline \multirow[t]{3}{*}{ A1 } & $800-224$ & 31 & 0.16 & 10.9 & Quartz $\left(\mathrm{SiO}_{2}\right)$ fluorite $\left(\mathrm{CaF}_{2}\right)$, calcite $\left(\mathrm{CaCO}_{3}\right)$ \\
\hline & $224-125$ & 67 & 14.0 & & \\
\hline & $<125$ & 2 & 16.6 & & \\
\hline \multirow[t]{3}{*}{ A2 } & $800-224$ & 23 & 0.44 & 5.01 & Quartz, fluorite, calcite, barite $\left(\mathrm{BaSO}_{4}\right)$ \\
\hline & $224-125$ & 76 & 3.37 & & \\
\hline & $<125$ & 1 & 20.5 & & \\
\hline \multirow[t]{3}{*}{ S1 } & $800-224$ & 30 & 8.96 & 23.1 & Quartz, fluorite, calcite, barite \\
\hline & $224-125$ & 68 & 28.2 & & \\
\hline & $<125$ & 2 & 31.6 & & \\
\hline
\end{tabular}



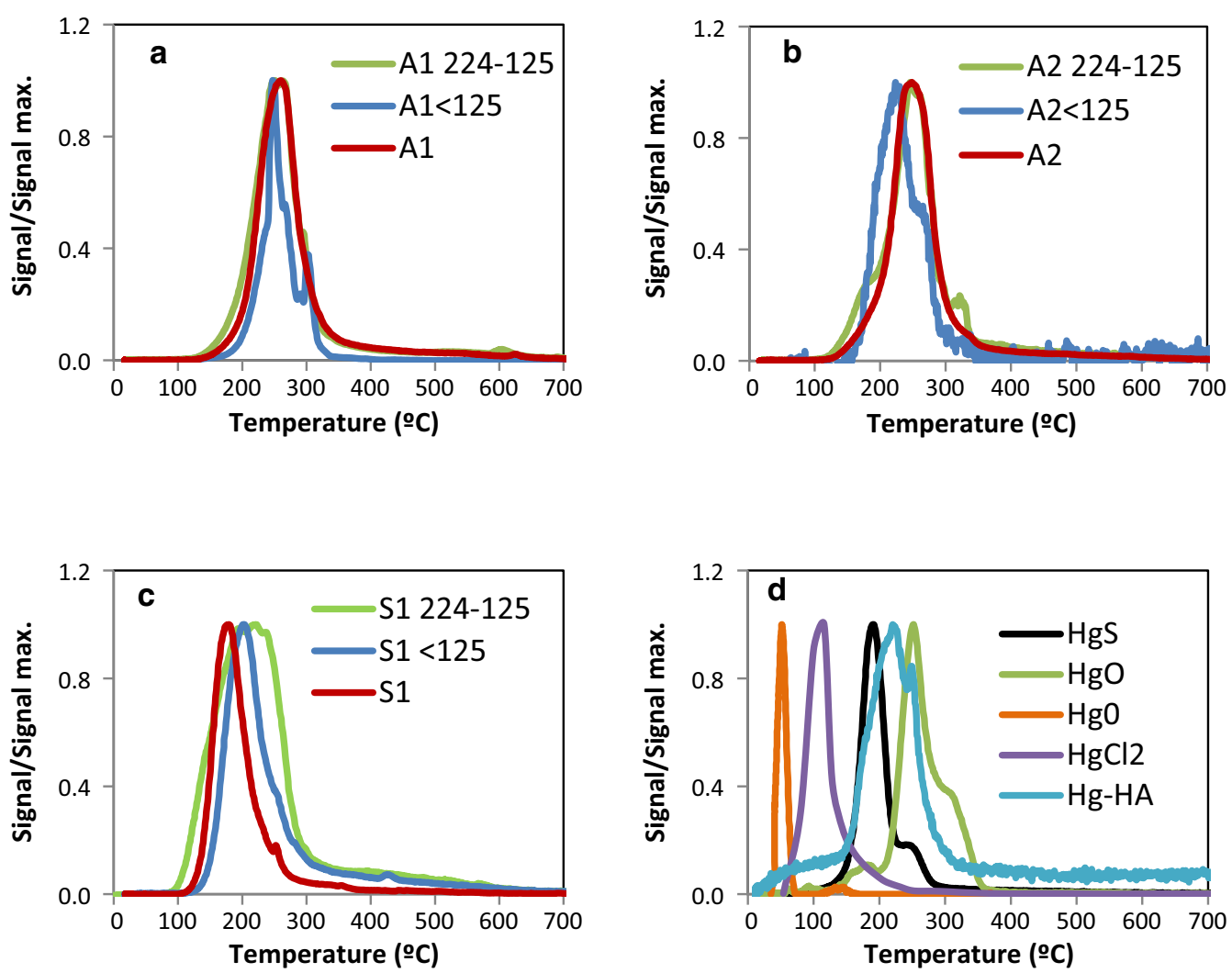

Fig. 2 Thermal profiles of A and B sand samples, C soil sample and D mercury pure compounds ( $\mathrm{HgS}, \mathrm{HgO} \mathrm{Hg}^{0}, \mathrm{HgCl}_{2}$ and $\left.\mathrm{Hg}-\mathrm{HA}\right)$

the maximum temperature peak of desorption is the same for each group of samples studied. Hence, the mercury species present in the samples do not vary with the mercury concentration and the particle size (Table 1 ). The thermograms of the mercury species from the beach sands (A1 and A2) analyzed show a maximum peak at $240 \pm 10^{\circ} \mathrm{C}$. This peak corresponds to the $\mathrm{HgO}$ pure mercury compound (Fig. 2d). However, in the case of the soil sample (S1), the temperature of maximum desorption is at $180 \pm 11{ }^{\circ} \mathrm{C}$. This peak is assigned to $\mathrm{HgS}$, the most abundant and stable mineral species of mercury in nature [43].
The analyses carried out by ICP-MS after sequential extraction and HPLC separation of mercury species show that inorganic mercury is the predominant form in the samples (Table 2). In fact, only in the soil sample very minor traces of organic mercury were found. In addition, Tessier's extracts of the samples revealed negligible amounts of mercury in all the fractions being the predominant fraction the residual one.

Table 2 (Left) Percentages of the five fractions obtained in the Tessier sequential extraction results; EX (exchangeable), CB (carbonate bound), OX (Fe/Mn oxides bound), OM (organic matter bound), and immobile fraction (residue), (Right) percentages of inorganic vs. organic mercury in the samples studied

\begin{tabular}{|c|c|c|c|c|c|c|c|}
\hline \multirow[t]{2}{*}{ Sample } & \multicolumn{5}{|c|}{$\% \mathrm{Hg}$ (sequential extraction) } & \multicolumn{2}{|c|}{$\%$ Chemical speciation } \\
\hline & EX & $\mathrm{CB}$ & ox & OM & Residue & $\mathrm{Hg}$ inorganic & Hg organic \\
\hline $\mathrm{A} 1$ & n.d & n.d & n.d & n.d & 100 & 100 & n.d \\
\hline$A 2$ & n.d & n.d & n.d & n.d & 100 & 100 & n.d \\
\hline S1 & 1.6 & 0.3 & 9.1 & 9.3 & 79.7 & 99.1 & 0.9 \\
\hline
\end{tabular}




\section{Discussion}

The HgTPD method has already demonstrated its capability for the identification of mercury species in different types of solids [3, 5, 36, 37]. However, its potential to explore the sources of contamination on a beach surrounded by mines and industries is a new issue. The identification of mercury species in similar samples was already been carried out by using other methods of analysis $[2,8,50]$, and in all cases the results were of great relevance from the environmental and social point of view. However, the HgTPD method entails some advantages when compared with X-ray absorption spectroscopy (EXAFS) and classic extraction methods, such as its low detection limit and high selectivity. The application of the HgTPD technique has been shown to be an effective means of identifying mercury species in two environmental compartments that are difficult to assess using more conventional techniques based on $\mathrm{Hg}$ chemical extraction. In fact, soils in former mining areas, and especially sandy sediments in coastal areas, usually present abundant refractory complex minerals such as silicates together with sulfides and oxides, leading to difficulties in the quantification or speciation of metals linked to them and requiring very strong acidic extractions. This problem was overcome in this study by the application of HgTPD.

The results obtained by HgTPD technique and confirmed by ICP-MS after sequential extraction and HPLC separation verify that mercury is present mostly in insoluble stable $(\mathrm{HgS})$ or low-mobility $(\mathrm{HgO})$ forms in the samples studied, while other possible mercury species such as $\mathrm{HgCl}_{2}, \mathrm{Hg}^{0}$ and mercury associated with humic acids (Hg-HA) are virtually absent.

On the basis of the mercury species identified in the samples and the industrial activities carried out in the zone studied, the possible sources of mercury contamination to be considered are the following:

$\mathrm{HgS}$, one of the mercury species identified in this study (Fig. 2), is found associated with different types of particles, such as airborne particulate matter [1,12] and fly ash particles [40]. Given that in Asturias there are four coal-fired power plants currently operating at less than $100 \mathrm{~km}$ from the Vega beach (Fig. 1a) and that coal power plants are the main source of anthropogenic mercury emissions, the particles emitted from coal combustion should be considered as one potential source of mercury in this particular area. However, in the samples analyzed in this study it cannot be confirmed whether the mercury came from coal or the particles produced by the process itself. If the contamination had come from air deposits, then the soil and the beach sand should have been similarly affected given their close proximity to each other but no $\mathrm{HgS}$ was detected in the beach sands (Fig. 2). Neither were any other mercury species, such as $\mathrm{HgCl}_{2}, \mathrm{HgSO}_{4}$ or $\mathrm{HgO}$ which are often present in coal fly ashes, detected $[28,40]$. It is also significant that the levels of mercury found in other beaches closer to the coal power plants than Vega beach were much lower $\left(0.13 \pm 0.01 \mu \mathrm{g} \mathrm{g}^{-1}\right.$ as an average value).

A second hypothesis could be the influence of former $\mathrm{Hg}$ mining and metallurgy activities that were carried out in the region up until the 1970 s and the subsequent abandonment of huge amounts of $\mathrm{Hg}$ waste. This is highly likely in the case of the sites known as La Soterraña [30], El Terronal [16] and their surroundings (Fig. 1a), as a consequence of which the river sediments in the hydrographic basin where these sites are located were also affected [19]. The effects are especially noticeable in the river mouth of the Nalón River, the main river in the region (see e.g., [17]. However, the distance between the $\mathrm{Hg}$ mining cores and the studied area, which is located in a different basin, would seem to rule out any possible relationship. In addition, previous studies on mercury speciation in the mining and metallurgy waste of the above-mentioned $\mathrm{Hg}$ sites of central Asturias [41] present different profiles to those of the mercury species obtained here, i.e., several mercury species such as metacinnabar, $\mathrm{HgCl}_{2}, \mathrm{Hg}-\mathrm{FeS}_{2}$ or even $\mathrm{Hg}(0)$ were present in Rumayor's study but not in this study of the Vega beach. Therefore, the second hypothesis seems very unlikely in the case of the present study.

As mentioned in the Results section, X-ray diffraction data of both the soil and the sand samples indicate the abundant presence of fluorite (Table 1, Additional file 1: Figure S1). This is clearly related to the proximity of several fluorite mines in the vicinity of the studied area, i.e., the so-called Caravia-Berbes mining district (Fig. 1b) where the paragenesis of the mineralization involves fluorite $\left(\mathrm{CaF}_{2}\right)$ and abundant barite $\left(\mathrm{BaSO}_{4}\right)[22$, 44 ], in coincidence with the minerals found in this study (Table 1, Additional file 1: Figure S1). Furthermore, cinnabar $(\mathrm{HgS})$ is present in the form of fine inclusions in the fluorite and copper minerals that are also plentiful in the area [22]. It is possible therefore that the extraction and treatment of fluorite in this zone could lead to contamination by mercury.

Furthermore, the differences in the speciation observed between the soil sample $(\mathrm{HgS})$ and those of the beach $(\mathrm{HgO})$ (Fig. 2) could be due to two different sources. On the one hand, the soils have been affected by the uncontrolled abandonment of nearby mining areas and therefore reflect the original mercury mineralogy, whereas on the other hand, the main source of mercury in the beach could have been the dumping (for decades) of mineral processing waste into the Vega river which flows into the sea next to the Vega beach [20]. The processing of fluorite 
which is mainly performed by means of flotation (see [51] and references therein) may cause a separation of $\mathrm{HgS}$ and $\mathrm{HgO}$ species in different fractions. In addition, although mercury is usually found as $\mathrm{HgS}$, other minerals such as montroydite $(\mathrm{HgO})$ may also be present in mine wastes [24], as is the case of the studied area. These facts would explain the differences found between the soil and sand samples. Stable and insoluble forms of mercury, such as HgS, show a different mobility pattern in soils to that of other more reactive species of mercury, and this determines the potential impact on groundwater and hence on the health of human beings [33].

\section{Conclusions}

Use of the HgTPD technique has made it possible to identify the presence of $\mathrm{HgO}$ in the beach sands and $\mathrm{HgS}$ in shoreline soil, while discarding the presence of other possible mercury species such as $\mathrm{HgCl}_{2}, \mathrm{Hg}^{0}$ or mercury associated with humic acids. The results have been corroborated by sequential extraction and HPLC-ICP-MS.

The mercury concentration is higher in the samples of the smallest particle size, but the thermal profiles are similar for the different fractions, suggesting that there is no change in the speciation of mercury.

Based on the mercury species identified and the industrial activities carried out in the area, the results suggest that the main source of pollution is the previous local fluorite mining activity. Other sources such as coal combustion or other practices involved in the exploitation of coal, and also mercury, in the region are unlikely.

In addition to contribute to understanding the behavior and the presence of mercury in the environment, this study is a relevant contribution to the validation of the desorption technique at programmed temperature.

\section{Supplementary information}

Supplementary information accompanies this paper at https://doi. org/10.1186/s12302-019-0264-3.

Additional file 1: Figure S1. X-ray diffraction patterns of sand samples (A1 and A2) and soil sample (S1).

\footnotetext{
Abbreviations

Å: Angstrom; A1: supratidal sand; A2: white dune; AMA: Advanced Mercury Analyzer; $\mathrm{B}$ : barite $\left(\mathrm{BaSO}_{4}\right)$ ); $\mathrm{BOPA}$ : Bulletin of Asturias (Spain) legislation; ${ }^{\circ} \mathrm{C}$ : Celsius degrees; $\mathrm{C}$ : calcite $\left(\mathrm{CaCO}_{3}\right)$; $\mathrm{CB}$ : fraction bound to carbonates; CSIC: Consejo Superior de Investigaciones Científicas. (Spanish National Research Council); Cu Ka radiation: $\lambda=1.54059 \AA$; E-PRTR: European Pollutant Release and Transfer Register; EX: fraction exchangeable; F: fluorite $\left(\mathrm{CaF}_{2}\right)$; g: grams; $\mathrm{Hg}^{0}$ : elemental gaseous mercury; HgTPD: mercury temperature-programmed desorption; HPLC: high-performance liquid chromatography; INDUROT: Institute of Natural Resources and Territorial Planning (University of Oviedo); ICP-MS: inductively coupled plasma mass spectrometry; km: kilometer; $\lambda$ : wavelength; $\mu \mathrm{g}$ : microgram; $\mu \mathrm{m}$ : micrometer; min: minutes; $\mathrm{mL}$ : milliliter; $\mathrm{mm}$ : millimeter; $n . d$ : non-detectable; OM: fraction bound to organic matter; OX: fraction bound to Fe and $\mathrm{Mn}$ oxides; Q: quartz $\left(\mathrm{SiO}_{2}\right)$; s: second; $\mathrm{S} 1$ : coastal soil
}

on the shoreline; UNEP: United Nations Environmental Program; URICI: Unit of Information Resources for Research; WHO: World Health Organization; \% wt: weight percentage; XRD: X-ray diffraction; $2 \theta$ : angle between the diffracted and transmitted X-ray.

\section{Acknowledgements}

The authors are grateful to the Environmental Assay Unit of the Scientific and Technical Services of the University of Oviedo for its technical support. We acknowledge the support of the publication fee by the CSIC Open Access Publication Support Initiative through its Unit of Information Resources for Research (URICI).

\section{Authors' contributions}

$J L R G$ is the person in charge of all the fieldwork. He has actively participated in the discussion of results. MAL-A is the coordinator of the work. She has participated from the design of the experimental part to the writing, interpretation and discussion of results. DMdIR has carried out the preparation and analysis of the samples by thermal desorption. ER-V and NG-G are the people in charge of sampling campaign, preparation and analysis by sequential extraction and ICP-MS. ER has carried out the preparation and analysis of the samples by XRD and has participated in the interpretation of the results. MRM-T has participated in the writing, interpretation and discussion of the results. All authors read and approved the final manuscript.

\section{Funding}

The study was part of the Ramón y Cajal contract (RYC-2013-12596) funded by the Spanish Ministry of Economy and Competitiveness and the project GRUPIN ID2018-000234 funded by Plan Regional I+D+i of Principado de Asturias (Spain)

\section{Availability of data and materials}

The datasets used and/or analyzed during the current study are available from the corresponding author on reasonable request.

\section{Ethics approval and consent to participate}

Not applicable.

\section{Consent for publication}

Not applicable.

\section{Competing interests}

The authors declare that they have no competing interests.

\section{Author details}

${ }^{1}$ INDUROT, Campus de Mieres, Universidad de Oviedo, 33600 Mieres, Spain.

${ }^{2}$ Instituto Nacional del Carbón (CSIC), Francisco Pintado Fe, 26, 33011 Oviedo, Spain.

Received: 22 April 2019 Accepted: 26 September 2019

Published online: 10 October 2019

\section{References}

1. Beldowska M, Saniewska D, Gębka K, Kwasigroch U, Korejwo E, Kobos J (2018) Simple screening technique for determination of adsorbed and absorbed mercury in particulate matter in atmospheric and aquatic environment. Talanta 182:340-347. https://doi.org/10.1016/j.talan ta.2018.01.082

2. Bełdowski J, Szubska M, Bełdowska M, Jankowska K, Kotlarska E, Graca B (2018) Seasonal changes of mercury speciation in the coastal sediments. J Soil Sediment 18:3424-3436. https://doi.org/10.1007/s1136 8-018-1993-4

3. Biester H, Gosar M, Covelli S (2000) Mercury speciation in sediments affected by dumped mining residues in the drainage area of the Idrija mercury mine, Slovenia. Environ Sci Technol 34:3330-3336. https://doi. org/10.1021/es991334V

4. Biester H, Muller G, Scholer HF (2002) Binding and mobility of mercury in soils contaminated by emissions from chlor-alkali plants. Sci Total Environ 284:191-203. https://doi.org/10.1016/S0048-9697(01)00885-3 
5. Biester H, Nehrke G (1997) Quantification of mercury in soils and sediments-acid digestion versus pyrolysis. Fresenius J Anal Chem 358:446452. https://doi.org/10.1007/s002160050444

6. Boente C, Matanzas N, García-González N, Rodríguez-Valdés E, Gallego JR (2017) Trace elements of concern affecting urban agriculture in industrialized areas: a multivariate approach. Chemosphere 183:546-556. https:// doi.org/10.1016/j.chemosphere.2017.05.129

7. BOPA, Boletín Oficial del Principado de Asturias, 91, April 21, 2014. Generic reference levels for heavy metals in soils from Principality of Asturias, Spain. http://sede.612asturias.es/bopa/2014/04/21/2014e06617 .pdf. Accessed Apr 2019

8. Chakraborty P, Babu PVR, Vudamala K, Ramteke D, Chennuri K (2014) Mercury speciation in coastal sediments from the central east coast of India by modified BCR method. Mar Pollut Bull 81:282-288. https://doi. org/10.1016/j.marpolbul.2013.12.054

9. Cheng X, Danek T, Drozdova J, Huang Q, Qi W, Zou L, Xiang Y (2018) Soil heavy metal pollution and risk assessment associated with the zn-pb mining region in yunnan, southwest china. Environ Monit Assess 190:194. https://doi.org/10.1007/s10661-018-6574-x

10. Eckley CS, Branfireun B, Diamond M, Van Metre PC, Heitmuller F (2008) Atmospheric mercury accumulation and washoff processes on impervious urban surfaces. Atmos Environ 42:7429-7438. https://doi. org/10.1016/j.atmosenv.2008.06.013

11. E-PRTR. The European Pollutant Release and Transfer Register (2016) http://prtr.ec.europa.eu/\#/pollutantreleases

12. Feng X, Lu J, Gregoire DC, Hao Y, Banic CM, Schroeder WH (2004) Analysis of inorganic mercury species associated with airborne particulate matter/ aerosols: method development. Anal Bioanal Chem 380:683-689. https:// doi.org/10.1007/s00216-004-2803-y

13. Fulkerson M, Nnadi FN, Chasar LS (2007) Characterizing dry deposition of mercury in urban runoff. Water Air Soil Poll 185:21-32. https://doi. org/10.1007/s11270-007-9396-y

14. Gai K, Hoelen TP, Hsu-Kim H, Lowry GV (2016) Mobility of four common mercury species in model and natural unsaturated soils. Environ Sci Technol 50:3342-3351. https://doi.org/10.1021/acs.est.5b04247

15. Gallego JLR, Ortiz JE, Sierra C, Torres T, Llamas JF (2013) Multivariate study of trace element distribution in the geological record of Roñanzas Peat Bog (Asturias, N. Spain). Paleoenvironmental evolution and human activities over the last 8000cal yr BP. Sci Total Environ 454-455:16-29. https:// doi.org/10.1016/j.scitotenv.2013.02.083

16. Gallego JR, Esquinas N, Rodríguez-Valdés E, Menéndez-Aguado JM, Sierra C (2015) Comprehensive waste characterization and organic pollution co-occurrence in a hg and as mining and metallurgy brownfield. J Hazard Mater 300:561-571. https://doi.org/10.1016/j.jhazmat.2015.07.029

17. Garcia-Ordiales E, Covelli S, Rico JM, Roqueñí N, Fontolan G, Flor-Blanco G, Loredo J (2018) Occurrence and speciation of arsenic and mercury in estuarine sediments affected by mining activities (Asturias, Northern Spain). Chemosphere 198:281-289. https://doi.org/10.1016/j.chemo sphere.2018.01.146

18. Gil-Díaz M, Alonso J, Rodríguez-Valdés E, Gallego JR, Lobo MC (2017) Comparing different commercial zero valent iron nanoparticles to immobilize Ss and Hg in brownfield soil. Sci Total Environ 584-585:1324-1332. https://doi.org/10.1016/j.scitotenv.2017.02.011

19. González-Fernández B, Rodríguez-Valdés E, Boente C, Menéndez-Casares E, Fernández-Braña A, Gallego JR (2018) Long-term ongoing impact of arsenic contamination on the environmental compartments of a former mining-metallurgy area. Sci Total Environ 610-611:820-830. https://doi. org/10.1016/j.scitotenv.2017.08.135

20. Gutiérrez Claverol M (2009) La fluorita: un siglo de minería en Asturias. 565 p. ISBN: 9788461325856

21. Higueras P, Fernández-Martínez R, Esbrí JM, Rucandio I, Loredo J, Ordóñez A, Alvarez R (2014) Mercury soil pollution in Spain: a review. Environment, energy and climate change. Handb Environ Chem 32:135-158

22. Iglesias JG, Loredo J (1994) Geological, geochemical and mineralogical characteristics of the Asturias fluorspar district, northern Spain. Explor Min Geol 1:31-37

23. Irabien MJ, Cearreta A, Leorri E, Gómez J, Viguri J (2008) A 130 year record of pollution in the Suances estuary (southern Bay of Biscay): implications for environmental management. Mar Pollut Bull 56:1719-1727. https:// doi.org/10.1016/j.marpolbul.2008.07.006
24. Kim CS, Brown GE Jr, Rytuba JJ (2000) Characterization and speciation of mercury-bearing mine wastes using $X$-ray absorption spectroscopy. Sci Total Environ 261:157-168. https://doi.org/10.1016/S0048-9697(00)00640 $-9$

25. Leorri E, Mitra S, Irabien MJ, Zimmerman AR, Blake WH, Cearreta A (2014) A 700 year record of combustion-derived pollution in northern Spain: tools to identify the Holocene/Anthropocene transition in coastal environments. Sci Total Environ 470-471:240-247. https://doi.org/10.1016/j. scitotenv.2013.09.064

26. Lohren H, Blagojevic L, Fitkau R, Ebert F, Schildknecht S, Leist M, Schwerdtle T (2015) Toxicity of organic and inorganic mercury species in differentiated human neurons and human astrocytes. J Trace Elem Med Biol 32:200-208. https://doi.org/10.1016/j.jtemb.2015.06.008

27. López-Alonso M, Benedito JL, Miranda M, Fernández JA, Castillo C, Hernández J, Shore RF (2003) Large-scale spatial variation in mercury concentrations in cattle in NW Spain. Environ Pollut 125:173-181. https:// doi.org/10.1016/S0269-7491(03)00073-3

28. López-Antón MA, Perry R, Abad-Valle P, Díaz-Somoano M, MartínezTarazona MR, Maroto-Valer MM (2011) Speciation of mercury in fly ashes by temperature programmed decomposition. Fuel Process Technol 92:707-711. https://doi.org/10.1016/j.fuproc.2010.12.002

29. Macsween K, Tang C, Edwards GC, Gan T, Tran S, Geremia S, Campbell J, Howard D (2017) Sampling of total mercury in sand on Sydney beaches and assessment of risk of exposure to children. Int J Environ Health 8:120-138. https://doi.org/10.1504/JENVH.2017.083974

30. Matanzas N, Sierra MJ, Afif E, Díaz TE, Gallego JR, Millán R (2017) Geochemical study of a mining-metallurgy site polluted with as and hg and the transfer of these contaminants to equisetum sp. J Geochem Explor 182:1-9. https://doi.org/10.1016/j.gexplo.2017.08.008

31. Millán R, Gamarra R, Schmid T, Sierra MJ, Quejido AJ, Sánchez DM, Vera R (2006) Mercury content in vegetation and soils of the almadén mining area (Spain). Sci Total Environ 368:79-87. https://doi.org/10.1016/j.scito tenv.2005.09.096

32. Navarro A, Cardellach E, Corbella M (2009) Mercury mobility in mine waste from Hg-mining areas in Almería, Andalusia (Se Spain). J Geochem Explor 101:236-246. https://doi.org/10.1016/j.gexplo.2008.08.004

33. O'Connor D, Hou D, OkY-S, Mulder J, Duan L, Wu Q, Wang S, Tack FMG, Rinklebe J (2019) Mercury speciation, transformation, and transportation in soils, atmospheric flux, and implications for risk management: a critical review. Environ Int 126:747-761. https://doi.org/10.1016/j.envin t.2019.03.019

34. Ordóñez A, Álvarez R, Loredo J (2013) Asturian mercury mining district (Spain) and the environment: a review. Environ Sci Pollut Res 20:74907508. https://doi.org/10.1007/s11356-013-1663-4

35. Pacyna EG, Pacyna JM, Sundseth J, Munthe J, Kindbom K, Wilson S, Steenhuisen F, Maxson P (2010) Global emission of mercury to the atmosphere from anthropogenic sources in 2005 and projections to 2020. Atmos Environ 44:2487-2499. https://doi.org/10.1016/j.atmosenv.2009.06.009

36. Reis AT, Coelho JP, Rodrigues SM, Rocha R, Davidson CM, Duarte AC, Pereira E (2012) Development and validation of a simple thermo-desorption technique for mercury speciation in soils and sediments. Talanta 99:363-368. https://doi.org/10.1016/j.talanta.2012.05.065

37. Reis AT, Coelho JP, Rucandio I, Davidson CM, Duarte AC, Pereira E (2015) Thermo-desorption: a valid tool for mercury speciation in soils and sediments? Geoderma 237-238:98-104. https://doi.org/10.1016/j.geode rma.2014.08.019

38. Rumayor M, López-Antón MA, Díaz-Somoano M, Martínez-Tarazona MR (2015) Device for identification of mercury species in solids. Consejo Superior de Investigaciones Científicas (CSIC). Patent ES1641.1031 Application number: P201530310

39. Rumayor M, Lopez-Anton MA, Díaz-Somoano M, Martínez-Tarazona MR (2015) A new approach to mercury speciation in solids using a thermal desorption technique. Fuel 160:525-530. https://doi.org/10.1016/j. fuel.2015.08.028

40. Rumayor M, Díaz-Somoano M, López-Antón MA, Martínez-Tarazona MR (2015) Application of thermal desorption for the identification of mercury species in solids derived from coal utilization. Chemosphere 119:459-465. https://doi.org/10.1016/j.chemosphere.2014.07.010

41. Rumayor M, Gallego JR, Rodríguez-Valdés E, Díaz-Somoano M (2017) An assessment of the environmental fate of mercury species in highly 
polluted brownfields by means of thermal desorption. J Hazard Mater 325:1-7. https://doi.org/10.1016/j.jhazmat.2016.11.068

42. Sierra C, Boado C, Saavedra A, Ordóñez C, Gallego JR (2014) Origin, patterns and anthropogenic accumulation of potentially toxic elements (PTEs) in surface sediments of the Avilés estuary (Asturias, northern Spain). Mar Pollut Bull 86:530-538. https://doi.org/10.1016/..marpo |bul.2014.06.052

43. Skyllberg U (2012) Chemical Speciation of mercury in soil and sediment. In: Environmental chemistry and toxicology of mercury. Wiley, Hoboken. pp. 219-258

44. Tejerina JJ, Zorrilla BJ (1980) Descripción geológica del distrito minero de Caravia-Berbes (Asturias). Bol Geol Min 91 (6):716-731

45. Tessier A, Campbell PG, Bisson M (1979) Sequential extraction procedure for speciation of particulate trace metals. Anal Chem 51:844-850

46. Tomiyasu T, Kodamatani H, Imura R, Matsuyama A, Miyamoto J, Akagi H, Horvat M (2017) The dynamics of mercury near Idrija mercury mine, slovenia: Horizontal and vertical distributions of total, methyl, and ethyl mercury concentrations in soils. Chemosphere 184:244-252. https://doi. org/10.1016/j.chemosphere.2017.05.123
47. UNEP, United Nations Environment Programme (2013) Global mercury assessment 2013: sources, emissions, releases and environmental transport. UNEP Chemicals Branch, Geneva

48. UNEP (United Nations Environment Programme) 2017 Minamata Convention on Mercury, 2017. https://www.mercuryconvention.org

49. WHO (World Health Organization) 2017 http://www.who.int/news-room/ fact-sheets/detail/mercury-and-health

50. Wolfenden S, Charnock JM, Hilton J, Livens FR, Vaughan DJ (2005) Sulfide species as a sink for mercury in lake sediments. Environ Sci Technol 39:6644-6648. https://doi.org/10.1021/es048874z

51. Zhang C, Sun W, Hu Y, Tang H, Yin Z, Guan Q, Gao J (2018) Investigation of two-stage depressing by using hydrophilic polymer to improve the process of fluorite flotation. J Clean Prod 193:228-235. https://doi. org/10.1016/j.jclepro.2018.05.055

\section{Publisher's Note}

Springer Nature remains neutral with regard to jurisdictional claims in published maps and institutional affiliations.

\section{Submit your manuscript to a SpringerOpen ${ }^{\odot}$ journal and benefit from:}

- Convenient online submission

- Rigorous peer review

- Open access: articles freely available online

- High visibility within the field

- Retaining the copyright to your article

Submit your next manuscript at $\gg$ springeropen.com 